\title{
Menentukan Condition Grade Kerusakan Struktur Bangunan Beton Dermaga Dengan Inspeksi Teknik dan Metode Perbaikannya
}

\author{
Sulardi \\ Prodi Teknik Sipil Universitas Tridharma Balikpapan \\ e-mail: sulardikm61@yahoo.com
}

\begin{abstract}
This research aims to provide an overview of condition grade of existing concrete of port have been used for 30 years and visually dull concrete conditions and indicated damage in the form of concrete blanket lamination, spalling, open concrete reinforcement and the condition has been corroded[4].The research method uses the test method of technical inspection in the form of visual condition inspection and rebar test, hardness test and compressive surface concrete with hammer test, compressive strength test of cordrilled core concrete, ultrasonic core quality test, concrete reinforcement concrete test and concrete carbonation test [2]. The results showed a decrease of compressive strength of existing concrete 18\%. The laminating depth reaches a depth of $14 \mathrm{~mm}$ and spalling reaches a depth of $24 \mathrm{~mm}$ with corrosive concrete reinforcement conditions. The quality of concrete core with UVPT is 3.6-4.2 and in good condition, the thickness of concrete cover is $22 \mathrm{Cm}$ and concrete blanket carbonation in splash zone has reached $6.8 \mathrm{~mm}$ and diarrhea is not splashed water $1.5 \mathrm{~mm}$. With regard to the findings of condition of damage and degradation of condition grade, it is recommended to improve the structure of concrete of port with chipping method of carbonated concrete surface, corrosion reinforced concrete reinforcement, grouting using flowable microconcrete material specification, concrete bond fixation with bonding agent and concrete protection with mastic coat material specification.
\end{abstract}

Keywords : Technical inspection, material degradation, splash zone.

\begin{abstract}
Abstrak
Penelitian ini bertujuan untuk memberikan gambaran condition grade bangunan beton dermaga eksisting yang telah digunakan selama 30 tahun dan secara visual kondisi beton kusam dan terindikasi kerusakan berupa laminasi selimut beton, spalling, tulangan beton terbuka dan kondisinya telah terkorosi [4].Metode penelitian menggunakan metode pengujian yaitu inspeksi teknik berupa pemeriksaan kondisi visual dan rebar test, uji kuat kekerasan dan tekan beton permukaan dengan hammer test, uji kuat tekan beton inti hasil cordrilled, uji kualitas inti betondengan ultrasonic, uji posisi tulangan beton terpasang dan pengujian karbonasi beton terpasang[2].Hasil penelitian menunjukan penurunan kuat tekan beton eksisting 18\%. Kedalaman laminating mencapai kedalaman $14 \mathrm{~mm}$ dan spalling mencapai kedalaman $24 \mathrm{~mm}$ dengan kondisi tulangan beton korosif. Kualitas inti beton dengan UVPT 3.6-4.2 dan dalam kondisi baik, tebal selimut beton rata-rata $22 \mathrm{Cm}$ dan karbonasi selimut beton diarea splash zone telah mencapai $6.8 \mathrm{~mm}$ dan diarea tidak terpercik air $1.5 \mathrm{~mm}$. Terhadap temuan kondisi kerusakan dan penurunan condition grade telah direkomendasi perbaikan struktur bangunan beton dermaga dengan metode chipping permukaan beton terkarbonasi, penggantian tulangan beton terkorosi, grouting menggunakan spesifikasi material flowable microconcrete, perbaikan ikatan beton dengan bonding agent dan proteksi beton dengan spesifikasi material mastic coat.
\end{abstract}

Kata Kunci : Inspeksi teknik, degradasi material, splash zone. 


\section{Pendahuluan}

\subsection{Latar Belakang Masalah}

Keberadaan dermaga menjadi bagian yang sangat penting dan vital dalam menunjang kelancaran operasi PT. Pertamina RU V Balikpapan. Pada saat ini PT. pertamina RU V mengoperasikan 11 (sebelas) dermaga type jetty dengan fungsi guna mendukung kegiatan loading-unloading (bongkar buat) crude oil (minyak mentah) dan bahan bakar minyak (BBM) ke kapal tangker untuk melayani kebutuhan bahan bakar wilayah Indonesia bagian tengah dan wilayah Indonesia bagian timur. Kapasitas bangunan dermaga/ jetty terpasang adalah untuk kapal tangker. 25.000 50.000 DWT.

Dermaga milik PT. Pertamina RU V pada awalnya adalah peninggalan pemerintah Hindia Belanda (BPM) yang dikembangkan pada tahun 1971 dan pada tahun 1983 oleh Pertamina menggunakan spesifikasi material mutu beton K-250. Pengembangan (refurbishment) dermaga dilakukan dalam rangka memenuhi tuntutan kebutuhan pengembangan kilang dengan kapasitas sandar kapal tangker dengan kapasitas hingga 25.000 DWT [2].

Permasalahan yang dihadapi oleh struktur bangunan dermaga Pertamina RU V adalah masalah degradasi material beton dermaga dan fasilitas penunjangnya seperti struktur pipe rack, face fender dan breasting dolphin. Secara visual truktur beton terlihat kasar dan kusam akibat terpapar bebas dilingkungan uap air laut. Kondisi beton yang kusam dan kasar mengindikasikan bahwa struktur beton telah mengalami degradasi material (korosif) [4], Degradasi material beton bukan saja terjadi dibagian permukaan tetapi diprediksi telah mencapai segmen selimut beton dan dikawatirkan telah merusak ikatan beton serta telah pula mengakibatkan terkorosinya tulangan beton [3] [4].

Penelitian ini penting untuk dilakukan guna mengetahui kualitas struktur beton dermaga eksisting agar dapat ditentukan derajat kerusakannya (condition grade) dan dapat ditentukan spesifikasi material, peralatan dan metode perbaikan yang akan digunakan.
Kegiatan penelitian ini dilakukan juga dalam rangka menunjang kesiapan operasi (readiness) dan kehandalan operasi (reliability performance) peralatan operasi kilang mendukung program nasional penyediaan bahan bakar minyak (BBM) di Indonesia.

\subsection{Permasalahan}

Selama ini pemeriksaan kondisi bangunan dermaga dilakukan dengan pengamatan visual saja dengancara mengamati kondisi fisik bangunan beton. Namun hasil pemeriksaan visual ini tidak efektif karena metode visual test hanya dapat memberikan gambaran visual saja dan tidak bisa menggambarkan kondisi internal betonnya. Untuk itu diperlukan pengujian lanjut seperti uji non destructive test (NDT) dan hasil uji destructive test (DT) sebagai evidence yang dapat mendukung kesesuaian antara rekomendasi dengan metode perbaikan. Hasil uji NDT dan DT juga sangat bermanfaat untuk ketepatan analisis dan diagnosa faktor dan penyebab permasalahan.

Untuk itu diperlukan inspeksi teknik terhadap kondisi bangunan beton dermaga yang meliputi pengamatan visual test, terhadap seluruh elemen struktur dermaga, pipe rack, bangunan trestle dan bangunan breasting dolphin. Pengujian kuat tekan beton inti dengan metode core drilled, pengujian kekerasan permukaan dengan metode hammer test, pengujian ultrasonic dengan metode UPVT, metode pengujian posisi tulangan beton dengan alat profometer dan metode pengujian karbonasi dengan larutan phenopthalein.

\subsection{Identifikasi Masalah}

Kondisi visual struktur beton dermaga, beton pipe rack dan struktur beton breasting dolphin yang secara visual terlihat kusam, tampilan permukaannya kasar dan mengalami perubahan warna beton. Hasil pemeriksaan visual lebih lanjut menemukan indikasi permukaan beton telah mengalami pengelupasan selimut beton (lamination), tersebarnya agregat dipermukaan dan rompal (spalling). Kondisi ini menunjukkan bahwa struktur bangunan beton telah mengalami penurunan kualitas, pengurangan dimensi, tidak 
dalam kondisi solid dan kemunduran mampu layan.

Berdasarkan prinsip service life and life cycle of building structures tergambarkan bahwa dengan bertambahnya umur pakai maka struktur beton akan cenderung mengalami kemunduran mampu layan (requirement performance) dan jika tidak ada upaya perbaikannya requirement performance struktur beton akan melampaui critical limit dan pada akhirnya struktur beton akan mengalami keruntuhan (failure) [1].

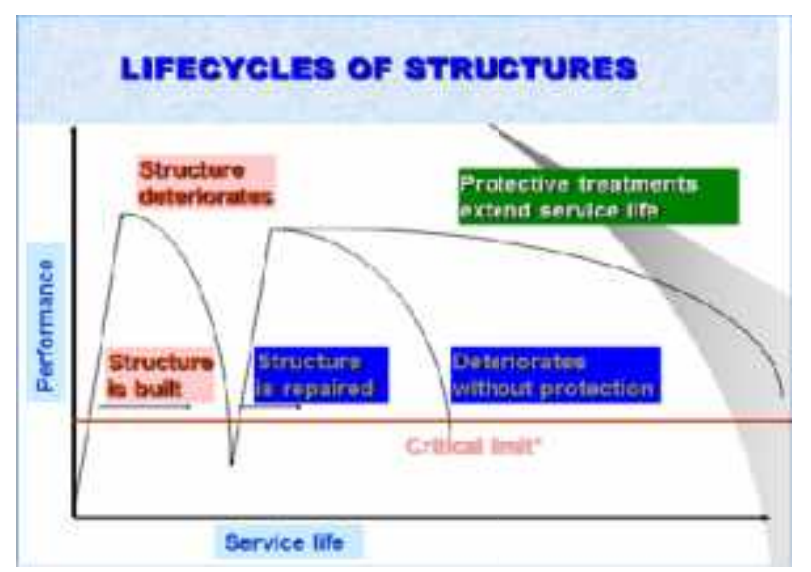

Gambar 1. Life cycle struktur beton terpasang

\subsection{Tujuan Penelitian}

1. Memberikan gambaran metode inspeksi teknik yang digunakan dalam pengujian kondisi bangunan beton dermaga eksisting

2. Memberikan gambaran condition grade kerusakan bangunan beton dermaga eksisting

3. Memberikan gambaran rekomendasi dan metode perbaikan yang akan dilakukan terhadap kerusakan bangunan beton dermaga.

\section{Tinjauan Pustaka dan Kerangka Pemikiran}

\subsection{Tinjauan Pustaka}

Menurut hasil penelitian Radomir Folic [1], Struktur beton yang berinteraksi dengan lingkungan secara mikro maupun makro. Untuk menggambarkan dampak yang ditimbulkan oleh pengaruh lingkungan perlu untuk mengetahui kondisi suhu permukaan, kelembaban dan kemungkinan adanya paparan uap air laut yang mengandung klorida. Respon beton terhadap kondisi lingkungan secara umum berupa penyusutan, pemuaian dan kembang susut akibat merespon kondisi suhu dan kondisi kelembaban, kedalaman karbonasi dan penetrasi klorida. Klasifikasi paparan lingkungan telah diberikan pada standar EN 1990. Dimana fokusnya ada pada struktur beton dan interaksinya dengan lingkungan termasuk diantaranya lingkungan air laut [4]. Penting untuk mencegah pengaruh negative lingkungan uap air laut dan menyesuaikan respon struktur beton dengan penyesuaian pada kualitas beton yang digunakan, semakin daktil beton maka semakin sulit lingkungan mempengaruhinya, sebaliknya semakin porus dan kualitas betonnya maka semakin mudah lingkungan merusaknya dengan apa yang dikenal dengan istilah degradasi material beton.

Dua fase kemunduran mampu layan struktur beton terpasang adalah [1]:

a. Fase awal (periode) dimana tidak ada pelemahan komponen beton yang nyata, kecuali lapisan pelindung selimut beton yang terjadi setelah beton berumur $>15$ tahun. Kerusakan yang terjadi berupa degragasi material selimut beton permukaan yang disebabkan oleh paparan klorida yang sering kita sebut dengan karbonasi

b. Fase propagasi atau fase lanjut yang terjadi dalam bentuk mekanisme kemunduran aktif yang semakin berkembang dan semakin meningkat bersamaan dengan berjalannya waktu.

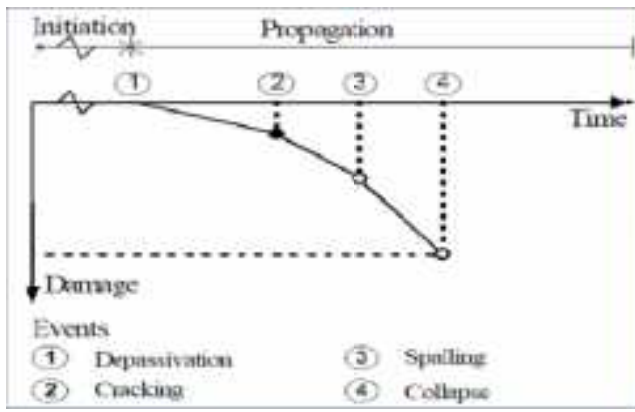

Gambar 1. Model fase kemunduran mampu layan struktur beton 
Periode propagasi terdiri dari propagasi dengan indikasi kerusakan minor dan periode percepatan terutama pada struktur yang telah memiliki durasi pemasangan $>15$ tahun dan setelah itu diikuti dengan periode akselerasi dengan meluasnya retak (crack) dan rompal (spalling) selimut pelindung beton.

\subsection{Kerangka Pemikiran}

Dari uraian permasalahan diatas dapat diketahui bahwa akar penyebab maalah (bad actor) degradasi material beton dermaga adalah lingkungan uap air laut. Namun hal ini bersifat keharusan (given), yakni struktur bangunan dermaga harus dibangun dikawasan pantai. Rekayasa enjiniring diperlukan untuk mengupayakan agar dapat menghambat degradasi beton eksisting dengan spesifikasi material yang berkualitas baik, peralatan kerja yang sesuai dan metode kerja yang sesuai untuk menghasilkan hasil perbaikan yang kualitasnya baik dan sesuai syarat-syarat keberterimaan (quality acceptance criteria).

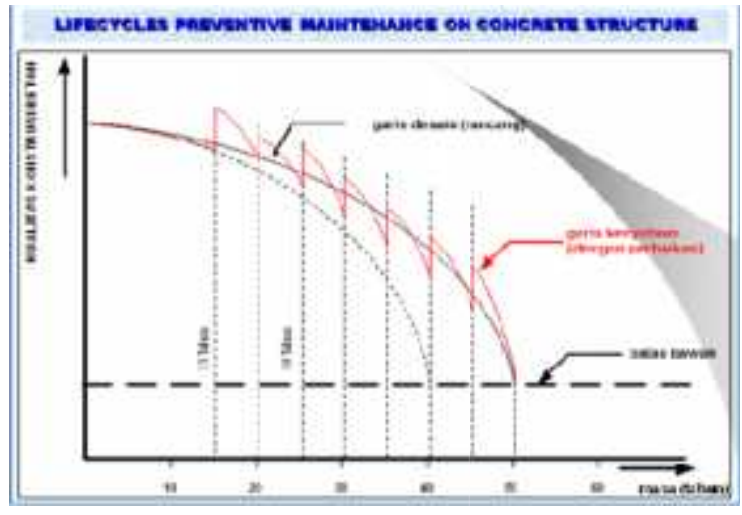

Gambar 2. Life Cycle of Structure Preventive Maintenance of Concrete

Berdasarkan gambar life cycle of structure preventive maintenance of concrete structure (gambar 2.2) dan gambar potential functional working life concrete dapat dikembangkan rekayasa enjiniring tindakan perbaikannya sebagai berikut :

1. Penurunan mampu layan struktur beton eksisting (sebelum mencapai crticial limit) dapat ditingkatkan kembali performance-nya sebagaimana kondisi desain dengan metode perbaikan menggunakan spesifikasi material sejenis namun dengan kualitas material yang lebih baik

2. Kualitas hasil perbaikan dipengaruhi oleh spesifikasi material perbaikan, ketersediaan peralatan kerja, metode kerja yang sesuai, quality control dan acceptance criteria yang sesuai serta dilakukan oleh pekerja yang memiliki pengetahuan dan pengalaman melakukan pekerja sejenis dengan hasil yang baik.

Dengan kualitas material beton yang baik dan sistim proteksi yang baik berpotensi memiliki umur pakai (service life) struktur beton yang lebih panjang.

\section{Metode Penelitian}

\subsection{Lokasi Penelitian}

Penelitian dilakukan pada bangunan dermaga (jetty) PT. Pertamina RU V Balikpapan dalam rangka menunjang kesiapan operasi (readiness) dan kehandalan operasi (reliability performance) peralatan operasi kilang mendukung program nasional penyediaan bahan bakar minyak (BBM) di Indonesia. Metode penelitian yang digunakan adalah metode inspeksi teknik yaitu dengan metode pengujian. Bangunan beton dermaga berada dikawasan pantai Teluk Balikpapan dengan type bangunan dermaga jetty yang menjorok sejauh 120 meter kearah laut dan dilengkapi dengan fasilitas pipe rack, face fender dan breasting dolphin.

Segmen bangunan yang dipilih adalah bangian bangunan beton yang terpercik (splash zone area) yakni area dibawah pelat lantai beton dan area diatas pelat lantai (upper zone area). Penentuan lokasi ini didasarkan pada kenyataan bahwa bangunan beton diarea splash zone memiliki kecenderungan lebih cepat mengalami degradasi (rusak) dibandingkan area yang tidak terpengaruh percikan air laut. Secara khusus pengujian dengan ultrasonic (UPVT) dilakukan pada segmen beam dan pier head saja.

\subsection{Metode Inspeksi Teknik}

\section{Pengamatan Visual}

Pegamanatan visual bertujuan untuk mengetahui kondisi visual bangunan. Metoda 
pemeriksaan secara visual dilakukan pada lokasi-lokasi yang telah ditentukan atau pada lokasi-lokasi kritis yang terindikasi mengalami kerusakan fisik yang dapat terlihat jelas untuk diamati. Pemeriksaan ini dilakukan dengan menginventarisasi segmen-segmen kerusakan fisik yang terjadi pada elemen struktur yang disertai pengambilan dokumenatasi, sehingga diharapkan semua data-data tersebut dapat tercatat dengan baik. Hal ini untuk mendukung dilakukan pemeriksaan lanjutan bilamana diperlukan ataupun sebagai basis data untuk pekerjaan baikan yang akan dilakukan.

\section{Uji Kuat Tekan Beton Inti}

Tujuan pengujian kuat beton inti adalah untuk mengetahui kondisi beton inti yaitu kondisi internal beton eksisting. Prinsip metoda pengujian beton inti (core-drilled) dilaksanakan menurut standar BS 1881, "Concrete Testing fir Strength" dan Standar Nasional Indonesia (SNI 03-2492-2002, Metode pengambilan dan pengujian beton inti dan SNI 03-6898-2002, Tata cara pelaksanaan pengambilan sampel dan pengujian kuat tekan beton inti. Tujuan pengujian core-drilled adalah menentukan kuat tekan beton sebenarnya (actual strength) dengan cara melakukan pengujian kuat tekan di laboratorium terhadap sampel yang diambil di lapangan. Pengambilan contoh spesimen benda uji dilakukan dengan cara coring, yaitu mengambil benda uji beton dari bagian struktur dengan ukuraan diameter $7,5 \mathrm{~cm}$ menggunakan mesin bor khusus.

\section{Uji Kekerasan Permukaan Beton (Hammer Test)}

Tujuan pengujian adalah untuk mengetahui kekerasan permukaan beton dipermukaan dapat dilakukan dengan alat uji palu beton (Hammer test) sesuai dengan standar ASTM C805-2. Metode uji ini diterapkan untuk menilai dan menguji keseragaman beton yang terpasang di lapangan, memberikan gambaran zona struktur beton yang memiliki kualitas buruk atau mengalami degradasi serta dan untuk mengestimasi pertumbuhan kuat tekan di lapangan. Metode uji hammer test ini tidak dimaksudkan sebagai dasar untuk penerimaan atau penolakan mutu beton, karena adanya ketidak pastian dalam estimasi kekuatan tekan beton. Hal lain yang perlu diperhatikan dalam pelaksanaan pengujian hammer test adalah elemen struktur beton yang akan diuji harus memiliki ketebalan minimal $100 \mathrm{~mm}$ dan terkoneksi erat dengan struktur bangunan dan area uji berdiameter $150 \mathrm{~mm}$. Hasil uji dengan menggunakan alat Hammer Test tergantung kepada rata dan tidaknya permukaan, basah keringnya bidang uji dan sudut inklinasi $0^{\circ}$, $90^{\circ} ;+90^{\circ}$ dan sudut $45^{\circ}$.

\section{Uji Kualitas dengan Ultrasonik (UPVT)}

Tujuan pengujian adalah untuk memperoleh gambaran kualitas beton mulai dari permukaan hingga didalam inti beton. Prinsip kerja pengujian ultrasonik adalah metode ASTM C597-83 dan BS 1881 : Part 203: 1986 dengan mengubah energi gelombang listrik yang dibangkitkan oleh pembangkit pulsa tranducer pengirim (T) menjadi energi gelombang mekanik yang selanjutnya merambat pada beton. Setelah sampai pada probe receiver $(\mathrm{R})$ energi gelombang tadi diubah kembali menjadi energi gelombang listrik yang selanjutnya melewati penguat dan dihitung / ditampilkan waktu tempuh tersebut dalam pencacah digital.

Pengukuran kecepatan rambat gelobang ultrasonik pada beton dinyatakan persamaan ; $\mathrm{V}=\mathrm{L} / \mathrm{T}$. Dimana, V adalah kecepatan rambat gelombang ultrasonik $(\mathrm{km} / \mathrm{sec})$; L adalah jarak tempuh $(\mathrm{mm})$ dan $\mathrm{T}$ adalah waktu tempuh gelombang ultrasonik $(\mu \mathrm{sec})$.

Tabel 1. Kualitas beton berdasarkan Uji UPVT

\begin{tabular}{|c|c|}
\hline $\begin{array}{c}\text { Kecepatan Rambat } \\
\text { Gelombang Ultrasonik } \\
\text { (UPV) }(\mathrm{km} / \mathrm{sec})\end{array}$ & $\begin{array}{c}\text { Kondisi/ Kualitas } \\
\text { Beton }\end{array}$ \\
\hline$>4.5$ & Sangat Baik \\
\hline $3.5-4.5$ & Baik \\
\hline $3.0-3.5$ & Cukup Baik \\
\hline $2.0-3.0$ & Buruk \\
\hline$<2.0$ & Sangat Buruk \\
\hline
\end{tabular}

\section{Uji Posisi Tulangan}

Metoda pengujian ini bertujuan untuk menentukan posisi tulangan, tebal selimut beton dan diameter tulangan menggunakan alat 
profometer yang terdiri dari : 1 buah probe universal untuk menentukan letak tulangan; tebal selimut beton dan dimensi tulangan. Prinsip pengujian adalah gunakan probe untuk mengetahui letak dari tulangan, setelah diketahui beri tanda dengan pensil / kapur. Kemudian cari letak tulangan berikutnya yang bersebelahan / sejajar sampai terdapat beberapa titik yang ada, lakukan pengukuran jarak pada titik-titik tersebut. Dari letak tulangan tersebut ukur juga ketebalan selimut beton dengan menggunakan probe dan untuk mengetahui dimensi tulangan letakkan probe pada lokasi yang sudah ditandai.

\section{Uji Karbonasi}

Metoda pengujian karbonasi bertujuan untuk mengetahui tingkat kedalaman karbonasi beton terpasang. Uji karbonasi untuk menentukan indikasi bahwa beton telah terkarbonasi dengan larutan Phenopthalein $\left(\mathrm{C}_{20} \mathrm{H}_{14} \mathrm{O}\right)$ sebagai indikator. Pengaruh karbonasi pada beon dapat diketahui dengan cara menyemprotkan larutan phenopthalein pada hasil core drill. Pengaruh phenopthalein pada beton adalah jika larutan phenopthalein pada beton berwarna merah, apabila inti $\mathrm{pH}$ beton > 8 maka beton bersifat basa) dan beton belum terkarbonasi. Sedangkan jika larutan phenopthalein pada beton tidak berwarna maka $\mathrm{pH}$ inti beton $<8$ maka beton bersifat asam dan beton telah dalam kondisi terkarbonasi.

\section{Hasil Penelitian dan Pembahasan \\ 4.1 Hasil Pemeriksaan dan Pengujian}

\section{Hasil Pengamatan Visual}

Hasil pemeriksaan visual ditemukan permukaan beton dermaga dengan kondisi agregat tersebar, selimut beton terlaminasi, beton spalling dan tulangan beton telah terkorosi.

Tabel 2. Hasil pemeriksaan visual

\begin{tabular}{|c|c|}
\hline Kondisi beton normal & Husil Pemziksaan rivual \\
\hline $\begin{array}{l}\text { Pemuikan betou berwama abu-aits, } \\
\text { cerat }\end{array}$ & 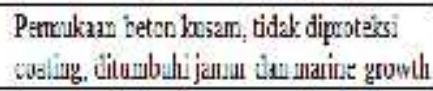 \\
\hline $\begin{array}{l}\text { Pemiksen hias, agrast tidak } \\
\text { tethat }\end{array}$ & 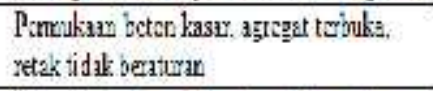 \\
\hline Seimut tetor halus, kondisiny taik & 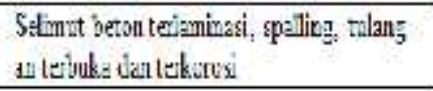 \\
\hline
\end{tabular}

Luas area kerusakan bangunan beton dermaga, bangunan beton pipe rack, bangunan beton trestle dan bangunan beton breasting dolphin adalah seluas $526,84 \mathrm{~m}^{2}$ atau $13.94 \%$ dari luas total struktur beton terpasang.

\section{Hasil Uji Kuat Tekan Beton Inti}

Benda uji beton inti adalah hasil cor drilled sebanyak 6 sampel dengan titik pengambikan di area splash zone 3 sampel dan diarea atas sebanyak 3 sampel. Pengujian kuat tekan aktual yang dilakukan Laboratorium uji beton, B4T Bandung.

Tabel 3. Hasil Uji Kuat Tekan Beton Aktual

\begin{tabular}{|c|c|c|c|}
\hline Lakas & 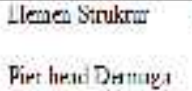 & 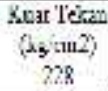 & 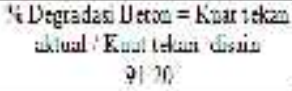 \\
\hline \multirow[t]{2}{*}{ Arrte Splash zeno } & Barn Pipe redk & 233 & 93.20 \\
\hline & Beus Treste & 238 & 95.20 \\
\hline \multirow{3}{*}{$\begin{array}{l}\text { Arsi PHif T.mui } \\
\text { anas }\end{array}$} & PAill Lutai Tresilr & 218 & . \\
\hline & PHall fimt.ii Drimily; & $\mathrm{n}$ & 9769 \\
\hline & Thes הing Domhtim & 237 & 9118 \\
\hline
\end{tabular}

Hasil uji beton inti (actual strength) yang tersebar pada 6 lokasi titik pengambilan sampel, kuat tekanya bervariasi, dari hasil pengujian diatas dinyatakan bahwa mutu beton memenuhi syarat > $90 \%$ dari mutu renana (K250).

\section{Hasil Uji Kekerasan Permukaan Beton (Hammer Test)}

Pengujian hammer test diambil pada lokasi-lokasi yang terdapat indikasi retakan dan pada lokasi disekitar pengambilan sampel core drilled.

Tabel 4. Hasil Hammer Test

\begin{tabular}{|c|c|c|c|c|}
\hline So & $\begin{array}{l}\text { El.mus } \\
\text { Struitue }\end{array}$ & $\begin{array}{c}\text { Nixi Menimun } \\
\left(\mathrm{Kg}\left(\mathrm{Cm}^{2}\right)\right.\end{array}$ & 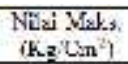 & 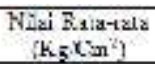 \\
\hline 1 & 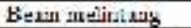 & 202 & 212 & $20 \%$ \\
\hline 2 & 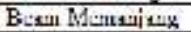 & 212 & 232 & 222 \\
\hline 3 & Pris & 708 & 220 & 214 \\
\hline 1 & F.e Eesul & 228 & 212 & 235 \\
\hline 5 & P.tal 1ardes alas & 224 & 232 & 228 \\
\hline E & Fuel ladei batrath & 231 & 237 & 234 \\
\hline
\end{tabular}

Hasil uji kekerasan permukaan dengan metode hammer test pada elemen struktur pier head memiliki tingkat kekerasan permukaan yang relatif lebih baik. Sedangkan pada elemen struktur beam melintang mempunyai nilai kekerasan permukaan terendah dibandingkan dengan elemen struktur yang lain. 


\section{Hasil Uji Kualitas dengan Ultrasonik}

Hasil pengujian dari kepadatan beton dimasing-masing elemen struktur beton menunjukkan tingkat kepadatan rata-rata tertinggi terdapat pada elemen struktur beton pier head, hal ini sesuai dengan nilai uji keseragaman permukaan beton pada beberapa lokasi yang menunjukkan kecenderungan lebih tinggi dibanding elemen struktur pier head dan longitudinal beam pada Dermaga No. 5 PT.Pertamina RU V Balikpapan.

Tabel 5. Hasil Uji UPVT beton terpasang

\begin{tabular}{|c|c|c|c|}
\hline \multirow[t]{2}{*}{ Lokasi } & $\begin{array}{l}\text { Teuis Dlemen } \\
\text { Sirniktur }\end{array}$ & $\begin{array}{l}\text { Nilai Rata-rata } \\
\text { IJP"I (om ses) }\end{array}$ & Ket erangan \\
\hline & Bcam Mclintan 5 & 3.90 & Baik: \\
\hline Denuaga & Ecam Mcmarjang & 3.85 & Baik \\
\hline $\mathrm{Ne} .5$ & Picr Hcd Donmaga & 3.86 & Baik \\
\hline & licr Hed 'Irestlo & 3.84 & Baik \\
\hline
\end{tabular}

Secara umum, hasil pengujian menunjukkan tingkat kepadatan beton pada seluruh elemen struktur masuk dalam kategori baik, hal ini terindikasi dengan kecepatan rambat gelombang ultrasonik berada pada pada kisaran 3,8 hingga 4,2 km/sec, inti beton dalam kondisi baik.

\section{Hasil Uji posisi tulangan}

Dari hasil penelusuran drawing design, didapat data kedalaman tulangan utama pada kisaran $26 \mathrm{~mm}$. Tebal lapisan selimut beton akan sangat mempengaruhi ketahanan struktur beton terhadap penetrasi klorida dari air laut. Semakin tebal lapisan selimut beton akan memperlambat kecepatan korosi pada tulangan dalam beton, hal tersebut akan berpengaruh pada usia layannya. Hasil uji posisi tulangan beton menunjukan posisi tulangan sebagai tersaji pada tabel. 5 .

Tabel 5.Hasil Uji Profometer beton dermaga

\begin{tabular}{|c|c|c|c|}
\hline Ledesí & Demen Struktu & 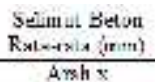 & Keteritry यू \\
\hline 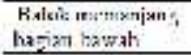 & 1..2n f, it ustinal $\mathrm{K}:$ sam & 21,7 & 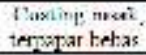 \\
\hline 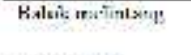 & Cin:mer Bingm & $7+y$ & $\begin{array}{l}\text { Thashinis mat. } \\
\text { tergarar tetas }\end{array}$ \\
\hline Pier Inesd 2 & Pier Deid & 22.0 & $\begin{array}{l}\text { Couting juszk. } \\
\text { tetzupau tetal }\end{array}$ \\
\hline D alac Kensol 2 & Daweb & 21,0 & $\begin{array}{l}\text { Costag suspk, } \\
\text { texpupal betas }\end{array}$ \\
\hline Pstat lentxi howash & Kax:4? & $22 \%$ & 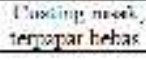 \\
\hline
\end{tabular}

*) Syarat SNI Beton 03-2847-2002, selimut beton untuk bangunan mMarine/ didaerah laut minimal $50 \mathrm{~mm}$.

\section{Hasil Uji Karbonasi}

Karbonasi dari beton merupakan hasil dari reaksi oksida kalsium dan penyimpangan dari pasta semen dengan udara yang mengandung karbon dioksida untuk membentuk kalsium karbonat yang mana akan mengurangi $\mathrm{pH}$ inti beton. Hal ini akan memicu beton secara kondusif untuk mengalami kerusakan. Kedalaman karbonasi terukur dengan menyemprot bagian beton yang baru terekspos dengan indikator larutan Phenolpthalein. Hasil uji karbonasi permukaan beton sebagaimana tersaji pada tabel. 6 .

Tabel 6.Hasil Uji Karbonasi beton dermaga

\begin{tabular}{|c|c|c|c|c|}
\hline \multirow[t]{4}{*}{ I.Aicusi } & $\begin{array}{l}\text { Finvoun } \\
\text { S.tukdur }\end{array}$ & 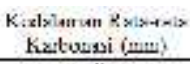 & $\begin{array}{c}\text { Sictimut Kivisr } \\
\text { (mun) }\end{array}$ & Selcumxen \\
\hline & & (I) & $(2)$ & \\
\hline & Pelat Atas : & 1.s & 24 & Teckertecnesi \\
\hline & Didsi $A x_{x+1}$ & 12 & 74 & 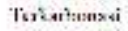 \\
\hline \multirow{5}{*}{$\begin{array}{l}\text { 13.rinape } \\
\text { Ne. } 5\end{array}$} & 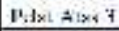 & 13 & 1) & 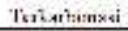 \\
\hline & Palint Atos 1 & 13 & 15 & Terharhonasi \\
\hline & Cxes Dear & 7.5 & $2 j$ & Teckirbenssi \\
\hline & Cress Dears & 5.5 & 24 & Texisurbenssi \\
\hline & Pria Hixil & 6.5 & 78 & 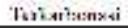 \\
\hline
\end{tabular}

Dari hasil uji karbonasi di elemen struktur beton yang telah ditentukan pada permukaan elemen struktur dermaga telah terindikasi karbonasi. Elemen struktur yang diuji pada umumnya adalah elemen struktur beton yang terpasang cukup, terpapar bebas dengan uap air laut dan tanpa proteksi coating.

\subsection{Pembahasan}

Dari analisis faktor dan penyebab permasalahan dapat disimpulkan bahwa faktor penyebab degradasi material beton dermaga terpasang adalah faktor lingkungan, yakni lingkungan uap air laut yang bersifat korosif. Dengan tools analisis 5 why's diketahui bahwa akar penyebab masalah (bad actor) korosi material beton terpasang adalah adanya kandungan Chloride $\left(\mathrm{Cl}^{-}\right)$didalam uap air laut. Selanjutnya dari gambaran peta kejadian degradasi material beton diketahui pula tahapan degradasi material beton terpasang meliputi tahapan karbonasi atau korosi permukaan beton, lanut dengan penetrasi Chlorida kedalam inti beton merusak sifat pasif inti beton, korosi tulangan beton dan kerusakan lanjut yang mengakibatkan beton mengalami kerapuhan dan penurunan mampu layan. 
Gambaran tahapan degradasi material beton sebagaimana tersaji pada gambar. 3 .

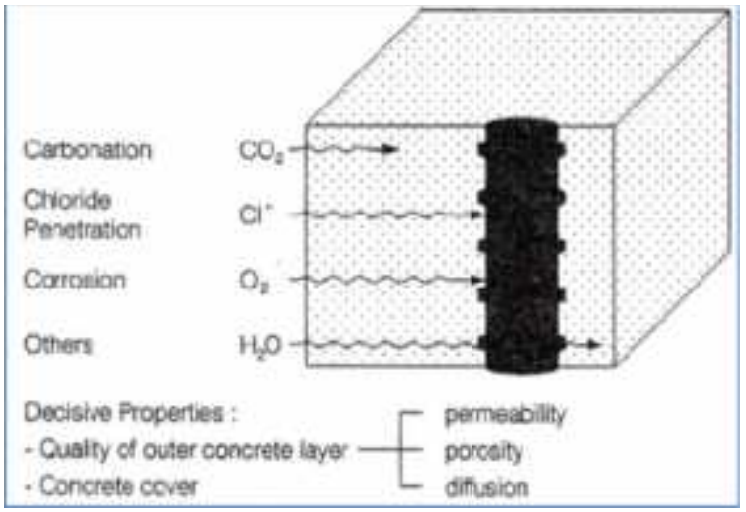

Gambar 3. Tahapan degradasi material beton

Proteksi permukaan beton dengan coating adalah upaya menghambat proses karbonasi dan chloride penetration kedalam beton. Untuk itu diperlukan spesifikasi material proteksi yang cocok dan resistance terhadap sifat korosif uap air laut agar material beton terpasang memiliki umur teknik yang lama. Proteksi beton dikawasan marine dapat dilakukan dengan mempertebal selimut beton, menggunakan spesifikasi material beton yang daktil dan menggunakan material mastic shield coating atau dengan dengan memadukan ketiganya untuk mendapatkan hasil yang maksimal.

Inspeksi teknik dengan visual test, Non destructive test dan destructive test sangat penting dilakukan untuk mengetahui derajat kerusakan (condition grade) material beton eksisting, memetakan jenis kerusakan beton eksisting sebagai evidence yang sangat peting menentukan rekomendasi perbaikan yang akan dilakukan. Didalam maintenance strategi dapat dilakukan dengan dua kegiatan yaitu preventive maintenance $(\mathrm{PM})$ dan repair maintenance (RM).

Preventive maintenance bersifat temporary maintenance atau cosmetic maintenance digunakan untuk tingkat kerusakan ringan, sedangkan repair maintenance bersifat permanent maintenance dan digunakan untuk tingkat kerusakan sedang. Requirement performance yang dicapai pada repair maintenance lebih baik dibandingkan dengan preventive maintenance. Spesifikasi material perbaikan, peralatan kerja, metode pelaksanaan perbaikan dan pengalaman melakukan pekerjaan sejenis sangat besar pengaruh terhadap kualitas hasil perbaikan sesuai requirement performance yang diharapkan.

\section{Penutup}

\subsection{Kesimpulan}

1. Metode inspeksi teknik dengan visual test, Non destructive test dan destructine test terbukti cocok dan sesuai digunakan untuk menentukan condition grade kerusakan beton dermaga terpasang karena hasil pengujian dapat mendukung dalam analisa dan penyusunan rekomendasi tindak lanjut

2. Condition grade kerusakan bangunan beton dermaga terpasang dapat menjadi guidance dalam penentuan tindak lanjut maintenance yang akan dilakukan, meliputi :

a. Penurunan condition grade $<5 \%$ dengan metode preventive maintenance

b. Penurunan condition grade $<10 \%$ dengan repair maintenance

c. Penurunan condition grade sampai $20 \%$ dengan metode repair maintenance and strengthening.

3. Rekomendasi perbaikan pada kerusakan beton dermaga PT. Pertamina RU V adalah :

a. Lakukan perbaikan dengan chipping permukaan beton yang terkarbonasi

b. Lakukan grouting dengan spesifikasi material flowable micro concrete dengan kuat tekan (CCS) min. $650 \mathrm{~kg} / \mathrm{Cm} 2$

c. Lakukan perbaikan ketahanan terhadap korosi dengan penggunaan selimut beton $>50 \mathrm{~mm}$ dan proteksi permukaan selimut beton dengan Anti Ultra Violet MasticSurface Tolerance coat

d. Setelah perbaikan selesai dilaksanakan, lakukan pengujian kualitas beton hasil perbaikan sebagaimana metode uji diatas dengan menambahkan uji kuat tariksambungan beton lama dan beton baru. 


\subsection{Metode Perbaikan}

1. Siapkan spesifikasi flowable microconcrete marine type dengan concressive strength min. $650 \mathrm{~kg} / \mathrm{am} 2$, anti korosi tulangan beton, bonding agent dan Anti UV Mastic Mastic Surface Tolerance Coating

2. Lakukan chipping selimut beton yang terkarbonasi dengan material hammer drill dan pastikan inti beton dalam kondisi baik dengan larutan phenopthalane. Chipping selimut beton dilakukan dengan metode papan catur untuk mencegah kegagalan struktur (failure)

3. Pasang bekisting (form work) dengan spesifikasi multiflex yang dilapisi film, dan dengan bentuk, dimensi, konfigurasi menyesuaikan kondisi aktual disite

4. Lakukan injeksi mortar dengan mesin sagola chamber dan pastikan mortar flowable microconcrete dapat mencapai lokasi perbaikan beton terjauh

5. Bekisting dilepas setelah mortar beton mengeras dengan baik, lakukan curing dengan menjaga kelembaban beton sampai dengan ikatan beton sempurna

6. Lakukan preparasi permukaan beton, bersihkan dengan angin dan lakukan coating anti UV Mastic tolerance coat dengan tebal min. 300 micron DFT.

\subsection{Ucapan Terimakasih}

Dengan telah selesainya inspeksi teknik ini Penulis mengucapkan terimakasih kepada Bapak Dedi Rachman dari Laboratorium uji beton B4T Bandung, Bapak Agung Wahyono dari PT. BASF Chemical Construction Jakarta dan Bapak Syafriansyah dari PT. Pertamina RU V Balikpapan yang telah banyak membantu sehingga lancarnya penelitian ini.

\section{Daftar Pustaka}

[1]. Radomir Folic, 2009, Durability Design of Concrete Structure, Analysis Fundamentals, Faculty of Technical Sciences Facta Universitatis, Serbia.

[2]. Sulardi, 2014, Inspeksi Teknik Struktur Bangunan Dermaga, Seminar Nasional Industri Dermaga Di Indonesia, B4T, Bandung

[3]. Sulardi, 2012, Metode Pelaksanaan Perbaikan Laminating, Gouting, Injection \& Strengthening Struktur Bangunan Dermaga, PT. Pertamina Corporate, Jakarta http://ptmkppwab81.pertamina.com/komet/sea rchResult.aspx?ptm;Kodefikasi AB9961

[4]. Sulardi, 2011, Analisis Panca Mutu Metode Perbaikan Struktur Dermaga PT Pertamina $R U V$ Balikpapan, Thesis Magister Teknik Sipil Universitas 17 Agustus 1945, Surabaya 